\title{
Anatomical changes on coffee leaves infected by Pseudomonas syringae pv. garcae
}

\author{
Lucas Mateus Rivero Rodrigues ${ }^{1,2,3}$, Rachel Benetti Queiroz-Voltan ${ }^{1}$, Oliveiro Guerreiro Filho ${ }^{1,4}$
}

\begin{abstract}
${ }^{1}$ Agronomic Institute of Campinas - SP, Brazil, Av. Theodureto de Camargo, 1.500, Campinas - São Paulo, Brazil; ${ }^{2}$ Postgraduate student in Tropical and Subtropical Agriculture, specialization in Genetics, Plant Breeding and Biotechnology; ${ }^{3} \mathrm{CAPES}$ research fellowship; ${ }^{4} \mathrm{CNPq}$ research fellowship. Autor para correspondência: Lucas M. R. Rodrigues (lucasmriverorodrigues@gmail.com)

Data de chegada: 12/11/2014. Aceito para publicação em: 14/04/2015.
\end{abstract}

$10.1590 / 0100-5405 / 2049$ \begin{abstract}
Summa Phytopathologica, v.41, n.4, p.256-261, 2015.
Although poorly studied, the bacterial halo blight is an important disease in the major coffee-producing states of Brazil. External damage and anatomical changes on leaves were measured in seedlings of Coffea arabica cv. Mundo Novo, susceptible to Pseudomonas syringae pv. garcae, by using histological sections obtained at 10 and 20 days after inoculation (DAI). The changes on the epidermis were smaller than the lesions measured in the mesophyll, irrespective of the evaluated colonization period, showing that the internal damage caused by the bacterium represent twice the damage observed externally. From the inoculation site, lysis occurred on the epidermal cells and on the palisade and
\end{abstract}

ABSTRACT

Rodrigues L.M.R., Queiroz-Voltan R.B., Guerreiro-Filho O. Anatomical changes on coffee leaves infected by Pseudomonas syringae pv. garcae

spongy parenchyma cells, with strong staining of their cellular contents, as well as abnormal intercellular spaces in the palisade parenchyma, hypertrophy and hyperplasia of mesophyll cells and partial destruction of chloroplasts. Additionally, this study revealed the presence of inclusion bodies in epidermal and mesophyll cells. Bacterial masses were found in the apoplast between and within mesophyll cells. Bacteria were also observed in the bundle sheath and vascular bundles and were more pronounced at $20 \mathrm{DAI}$, not only near the inoculation site but also in distant areas, suggesting displacement through the vascular system. These results can be useful to understand this plant-pathogen interaction.

Keywords: Anatomy, Coffea arabica, plant-pathogen interaction, bacterial halo blight.

\section{RESUMO}

Rodrigues L.M.R., Queiroz-Voltan R.B., Guerreiro-Filho O. Alterações anatômicas em folhas de cafeeiros intectados por Pseudomonas syringae pv. garcae. Summa Phytopathologica, v.41, n.4, p.256-261, 2015.

Apesar de pouco estudada, a mancha-aureolada é uma importante doença nos principais Estados produtores de café do Brasil. Os danos externos e as alterações anatômicas em folhas foram mensurados em mudas de Coffea arabica $\mathrm{cv}$. Mundo Novo, suscetível a Pseudomonas syringae pv. garcae a partir de cortes histológicos realizados aos 10 e 20 dias após a inoculação (DAI). As alterações na epiderme foram menores do que as lesões mensuradas no mesofilo, independente do período de colonização avaliado, mostrando que os danos internos causados pela bactéria representam o dobro do observado externamente. A partir do ponto de inoculação, foi verificado lise das células epidérmicas e dos parênquimas paliçádico e esponjoso, com forte coloração de seus conteúdos celulares, espaços intercelulares anormais no parênquima paliçádico, hipertrofia e hiperplasia das células do mesofilo e destruição parcial de cloroplastos. Além disso, este estudo revelou a presença de corpos de inclusão em células da epiderme e do mesofilo. Massas bacterianas foram encontradas no apoplasto entre e dentro de células mesofílicas. Bactérias também foram observadas na bainha do feixe e em feixes vasculares, sendo a ocorrência bacteriana, mais pronunciada aos $20 \mathrm{DAI}$, não apenas próximo ao ponto de inoculação, mas também, em regiões distantes, sugerindo seu deslocamento pelo sistema vascular. Estes resultados podem ser úteis na compreensão da interação planta-patógeno.

Palavras-chave: Anatomia, Coffea arabica, interação planta-patógeno, mancha-aureolada-do-cafeeiro.

Bacterial halo blight of coffee (Coffea arabica L.), which is caused by Pseudomonas syringae pv. garcae (1,21), was first observed in 1955 on coffee plants at Garça county, São Paulo State, Brazil. Currently, the disease is widespread in the major coffee-producing states. Outside Brazil, there are reports of its occurrence in Kenya (13), Ethiopia (8), Uganda and China (4). Influenced by weather conditions, this disease causes significant production losses and can be a limiting factor for the cultivation of coffee in areas with high rainfall and intense exposure to the wind, which provide ideal conditions for the pathogen infection and development (16). Occurrence of bacterial halo blight in nurseries can preclude the trade in plants. Zambolim et al. (20) suggests that preventing the disease entry in the crops is still the best control method. Moreover, the disease causes burning of the plant apex, characterized by necrosis of younger tissues, followed by sprouting of lateral buds, delaying the seedling development (5). In addition, it can cause seedling death. Furthermore, diseased or asymptomatic planting material may result in epidemics in the field, which can be of difficult effective control.

In the field, bacteria can infect various plant organs such as branches, flowers, fruits and mainly young leaves, on which the observed lesions are irregular and dark brown. On mature leaves, lesions are surrounded by the yellow halo that is characteristic of this disease (5). Chlorosis induction around the lesions is attributed to the synthesis and release by the bacterium of a dipeptide containing tabtoxinine- $\beta$-lactam, which irreversibly inhibits the enzyme glutamine synthetase. Without this enzyme, the plant cannot detoxify ammonia efficiently. Additionally, the thylakoid membrane of the chloroplast often ruptures, and there is an uncoupling of photophosphorylation 
$(2,3)$.

Understanding the alterations on coffee leaves induced by pathogenic organisms such as Xylella fastidiosa (12) and Colletotrichum gloeosporioides $(11,19)$ plays an important role in the comprehension of infection/colonization mechanisms and helps assess the damage caused by these pathogens.

Cellular changes in the structural anatomy of coffee leaves infected by $P$. syringae pv. garcae has not been reported yet. The current study was conducted in order to interpret details of some aspects on the morphology of coffee leaves infected by P. syringae pv. garcae, as well as to elucidate the pattern of bacterial colonization in infected plants. Results are expected to be useful to the understanding of the plant-pathogen interaction.

\section{MATERIALS AND METHODS}

A virulent strain of $P$. syringae pv. garcae IBSBF 1197 (Phytobacteria Culture Collection of the Instituto Biológico, Campinas, SP - Brazil), characterized by Rodrigues et al. (14) as highly aggressive to $C$. arabica cv. Mundo Novo, was used to inoculate coffee seedlings.

Bacterial suspension used as inoculum was prepared from cultures grown for $48 \mathrm{~h}$ on nutrient agar medium ( $0.5 \%$ peptone, $0.3 \%$ meat extract, $0.1 \% \mathrm{NaCl}$ and $18 \mathrm{~g}$ agar in 1 litre of distilled water), suspended in saline $(0.85 \% \mathrm{NaCl})$ and standardized in spectrophotometer to contain approximately $3 \times 10^{8} \mathrm{CFU} \cdot \mathrm{mL}^{-1}\left(\mathrm{~A}_{600}=0,25\right)$.

Seedlings of the cultivar Mundo Novo IAC 376-4, approximately six months age, were inoculated on the third pair of leaves (from the apex). The inoculation was performed at two points on each side of the midrib of coffee leaves by using an entomological pin 00 previously immersed in a bacterial suspension. Control plants were inoculated only with saline. Plants were kept in a humid chamber for $72 \mathrm{~h}$ after inoculation and then transferred to a greenhouse with high relative humidity.

The experiments were conducted in a completely randomized block design as factorial arrangement. Plants were inoculated in five replicates and the control treatment in three replicates.

Histopathologic features of infected leaves were investigated at 10 and 20 days after inoculation (DAI) by means of anatomical analysis under a light microscope. The observed lesions on the leaves were sectioned, fixed in FAA solution (formaldehyde-acetic acidethyl alcohol 50\%) (7), exposed to a vacuum for $48 \mathrm{~h}$, dehydrated in an ethanol-xylol series and embedded in paraffin. Paradermic cross sections of $12 \mu \mathrm{m}$ were obtained with a manual rotary microtome and subsequently distended/stretched and bonded to a piece of glass with Haupt's adhesive (7). Sections were stained with safranin, followed by Alcian Blue and mounted in Permount ${ }^{\circledR}$. Analyses were performed under an optical microscope, Leica's DMLB model, coupled to a camera for image capture and subsequent analysis in Motic Image Plus.

Magnitude of the damage on the epidermis and in the mesophyll at 10 and 20 DAI was evaluated by measuring the longest external lengths of lesions. Similarly, damage to mesophyll structures was evaluated in a cross section of the palisade and spongy parenchyma of the affected tissue. Statistical analyses were performed by means of Statistica 7.0. (17) The mean lesion size was compared by using the Student-NewmanKeuls test (18) at a significance level of 5\%.

\section{RESULTS}

Rapid development of bacterial halo blight symptoms was observed on $C$. arabica cv. Mundo Novo IAC 376-4, known by its highly susceptibility to the pathogen. Analysis of variance of the damage on the leaf tissues (Table 1$)$ showed a significant difference $(\mathrm{F}=8.57 ; \mathrm{P}=$ 0.0021 ) between the average damage observed on leaves at 10 and 20 DAI. Lesions at 20 DAI $(12.89 \mathrm{~mm})$ were characterized by tissue that was more necrotic and approximately twice the size of lesions observed at $10 \mathrm{DAI}(6.75 \mathrm{~mm})$. The lesions were surrounded by a yellow halo, consequence of chlorosis of leaf tissues.

In addition, the damage on inoculated leaves was statistically different in the three types of leaf tissues: epidermis, palisade and spongy parenchyma. Lesions on the epidermis $(6.64 \mathrm{~mm})$ were smaller than those in the palisade $(10.98 \mathrm{~mm})$ and spongy parenchyma $(11.83$ $\mathrm{mm})$.

The presence of scar tissue around the inoculation site was observed only in the mesophyll of plants inoculated with saline (Figure 1A and B). Near this tissue, epidermal cells and mesophyll parenchyma showed no anatomical abnormalities. The chloroplasts were intact, the palisade parenchyma cells remained compactly packed together, and the spongy parenchyma cells were arranged in a three-dimensional network interspersed with intercellular space (Figures $1 \mathrm{C}$ and D).

At 10 DAI, cellular changes such as lysis of epidermal and mesophyll cells (Figure 2A) with strong staining of their cell contents were observed around the inoculation point. In the epidermal cells, the presence of granular contents was noted, and the palisade parenchyma had intercellular spaces and hypertrophy of some cells (Figure 2C). Spongy parenchyma also showed partial destruction of chloroplasts, as well as masses of bacteria within cells and in the intercellular spaces of

Table 1. Mean values of damaged tissues (mm) in coffee seedlings of Mundo Novo IAC 376-4 cultivar caused by $P$. syringae pv. garcae at 10 and 20 days after inoculation.

\begin{tabular}{|c|c|c|c|}
\hline \multirow{2}{*}{ Damaged tissue } & \multicolumn{3}{|c|}{ Days after inoculation } \\
\hline & 10 & 20 & Mean \\
\hline & \multicolumn{3}{|c|}{ 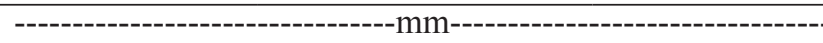 } \\
\hline Palisade parenchyma & 7.28 & 14.68 & $10.98 \mathrm{~b}$ \\
\hline Spongy parenchyma & 7.60 & 16.06 & $11.83 \mathrm{~b}$ \\
\hline $\mathrm{CV}(\%)$ & \multicolumn{3}{|c|}{30.62} \\
\hline
\end{tabular}

* Means followed by the same letter are not statistically different according to Student Newman-Keuls test at 5\% probability. 


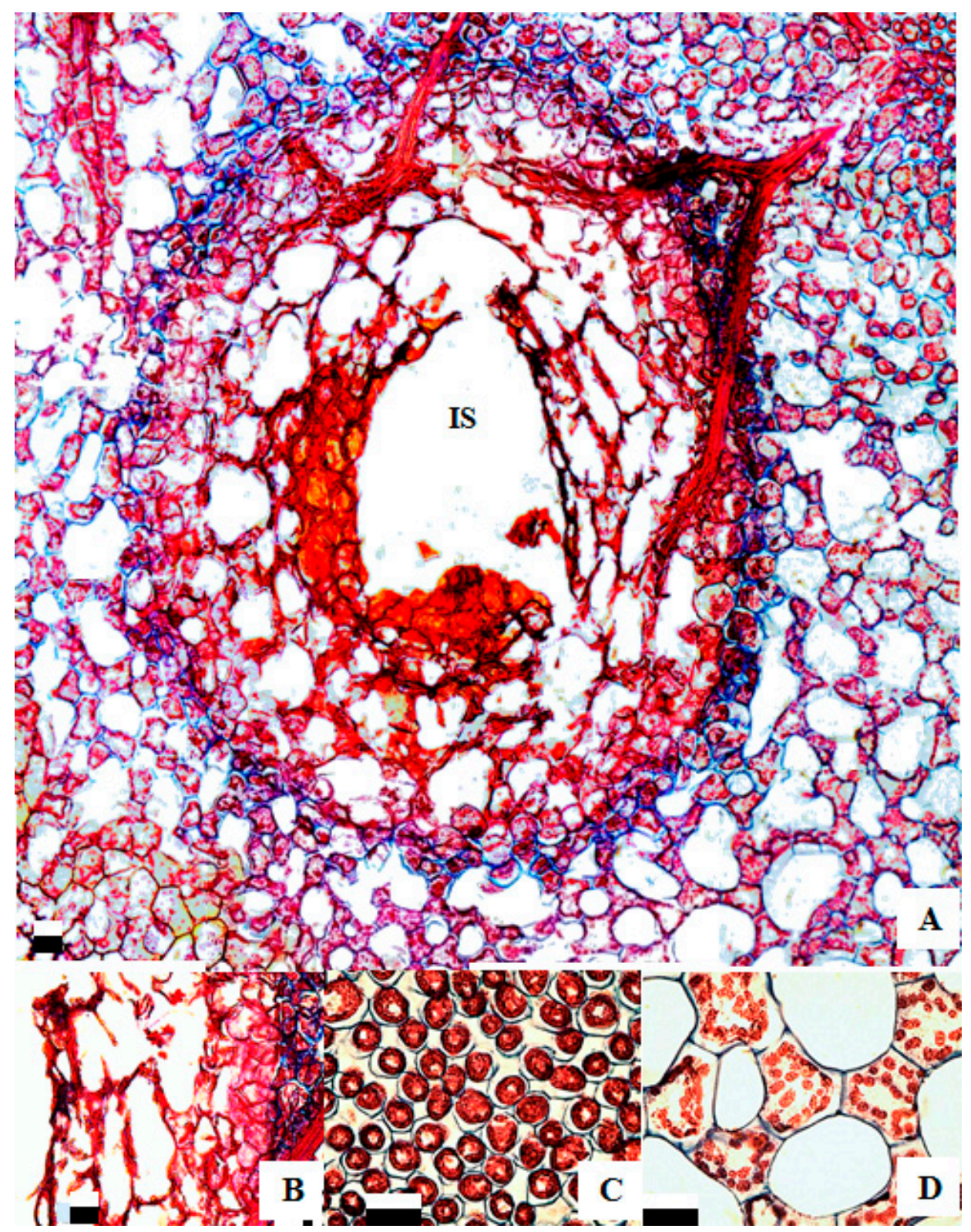

Figure 1. Paradermal section of control plants showing the mesophyll in the inoculation site (A); Wounded periderm (B); details of the palisade parenchyma (C); spongy parenchyma (D); IS = inoculation site. $($ Bar $=25 \mu \mathrm{m})$.

the mesophyll (Figure 2B and D). The mesophyll region had partially destroyed chloroplasts corresponding to the external characteristic of mild chlorosis around the lesion.

Bacteria colonized not only the intercellular spaces, but also inside mesophyll and parenchyma cells around the secondary vascular bundles and the vascular bundles themselves (Figure 2E). Bacteria were also present in the vessels of the xylem and phloem and apparently blocked them (Figure 2F).

At 20 DAI, many mesophyll cells were totally disrupted, not only near the inoculation site but also in distant areas (Figure 3A). External symptoms trace the path of ribs and thus reveal the presence of bacteria in the vascular bundles (Figure 3B). In transverse sections of the leaf blade, the destruction of chloroplasts in the mesophyll at 20 DAI was intense and was followed by hypertrophy and hyperplasia, mainly in the spongy parenchyma, which was in turn followed by a decrease in intercellular spaces (Figures $3 \mathrm{C}$ and $\mathrm{D}$ ) and intense production of bacterial mass (Figure 3E). Inclusions were also observed on both sides of the epidermis and in the mesophyll (Figure 3F).

\section{DISCUSSION}

The obtained results are important to elucidate the morphological alterations on young coffee leaves infected by $P$. syringae pv. garcae. The observed anatomical changes are similar to the tabtoxin damage induced by bacteria, which causes degradation of the thylakoid membrane and chloroplasts (3), and favors the tissue colonization and its use as substrate. The alterations described by Palmer \& Bender (10) for tomato inoculated with $P$. syringae were clearly identified in this study and demonstrated that chlorosis in diseased plant tissues 


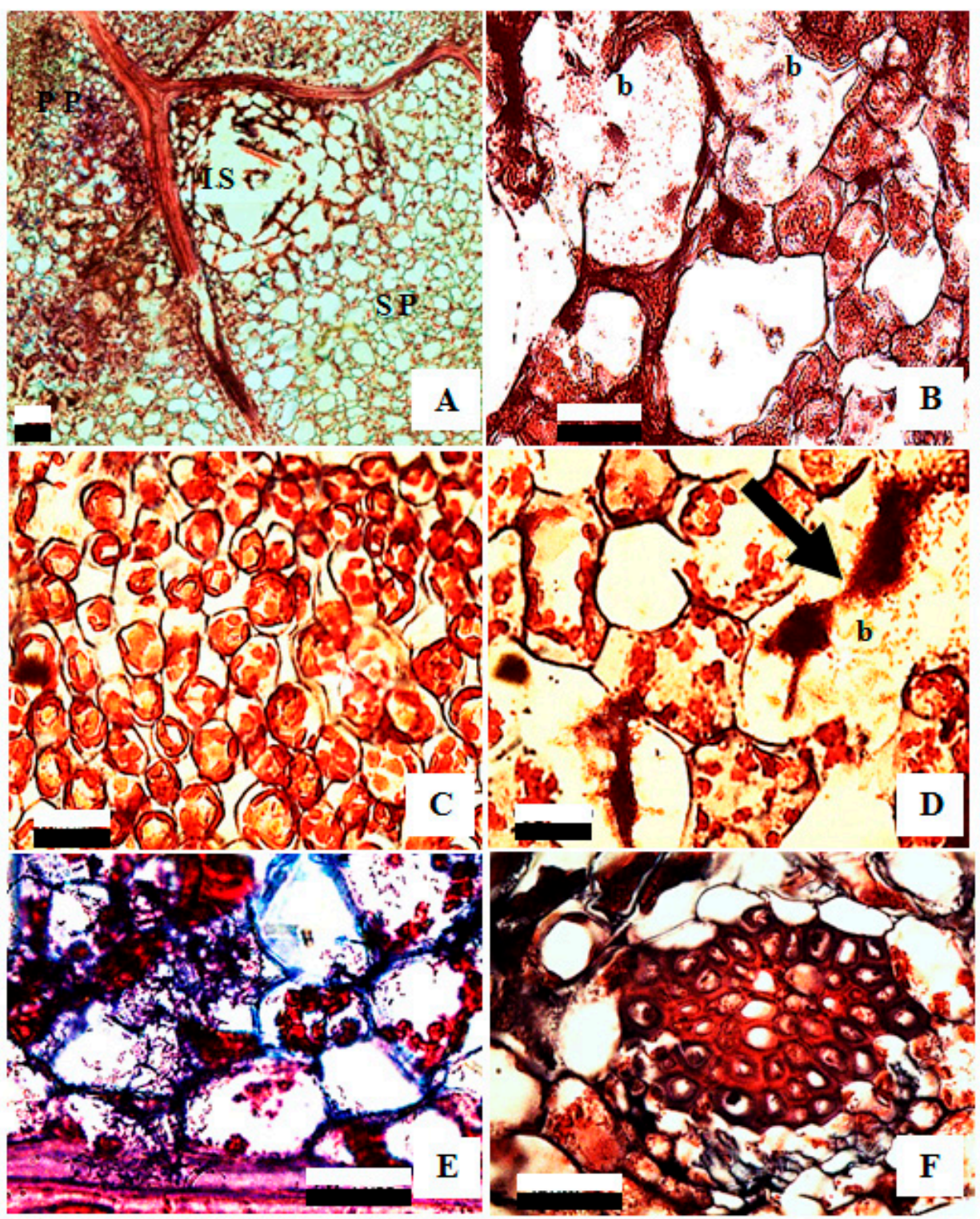

Figure 2. Paradermal section showing the mesophyll in the inoculation site at 10 DAI (A); spongy parenchyma showed partial destruction of chloroplasts, as well as masses of bacteria within cells and in intercellular spaces (B); palisade parenchyma (C); spongy parenchyma with bacterial masses (D); and the vascular bundles themselves (E). Transverse section of leaf showing cells of the vascular bundles blocked by bacteria and unstructured phloem $(\mathrm{F}) . \mathrm{b}=$ bacteria; IS = inoculation site, PP = palisade parenchyma; $\mathrm{SP}=$ spongy parenchyma. $(\mathrm{Bar}=25 \mu \mathrm{m})$.

corresponds to approximately double the damage that can be observed externally. Furthermore, Palmer \& Bender (10) observed plasmolysis of the cellular content in tomato mesophyll, as well as cell hypertrophy and hyperplasia. Similar changes were here observed in the mesophyll of coffee leaves at 20 DAI (Figure 2).

On nature, coffee leaves are infected by bacteria through stomata or wounds caused mainly by sand particles carried by the wind (5). After penetration into the leaf tissue, bacteria occupy inter- and intracellular spaces, as shown in Figure 2, invade the vascular system and rapidly colonize the tissues, forming large lesions, even in regions farther away from the inoculation site (Figure 3A). This strategy is known for some phytobacteria and our results were similar to studies conducted by Roos \& Hattingh (15), in which the bacterium P. syringae pv. morsprumorum colonizes leaves of sweet cherry (Prunus avium) and was detected at $3 \mathrm{~cm}$ or farther from the inoculation site at $10 \mathrm{DAI}$. Occlusions in the vascular bundles of veins that were in contact with advancing margin of colonized mesophyll tissue of cherry and coffee leaves were also observed in this study (Figure 3F). In the interaction of inoculated tobacco (Nicotiana benthamiana) with P. syringae pv. syringae, Misas-Villamil et al. (9) demonstrated a similar procedure of tissue colonization distant from the inoculation site, using the xylem vessels to get around through the leaf blade; this feature is evidenced as an important property of these pathogens.

Roos \& Hattingh (16) and Hattingh et al. (6) suggests that the bacteria $P$. syringae pv. morsprumorum and P. syringae pv. syringae have the same penetration behavior in the hosts, i.e., they penetrate through stomata and are initially limited to the mesophyll intercellular spaces near the inoculation site. Then, they penetrate the parenchyma 


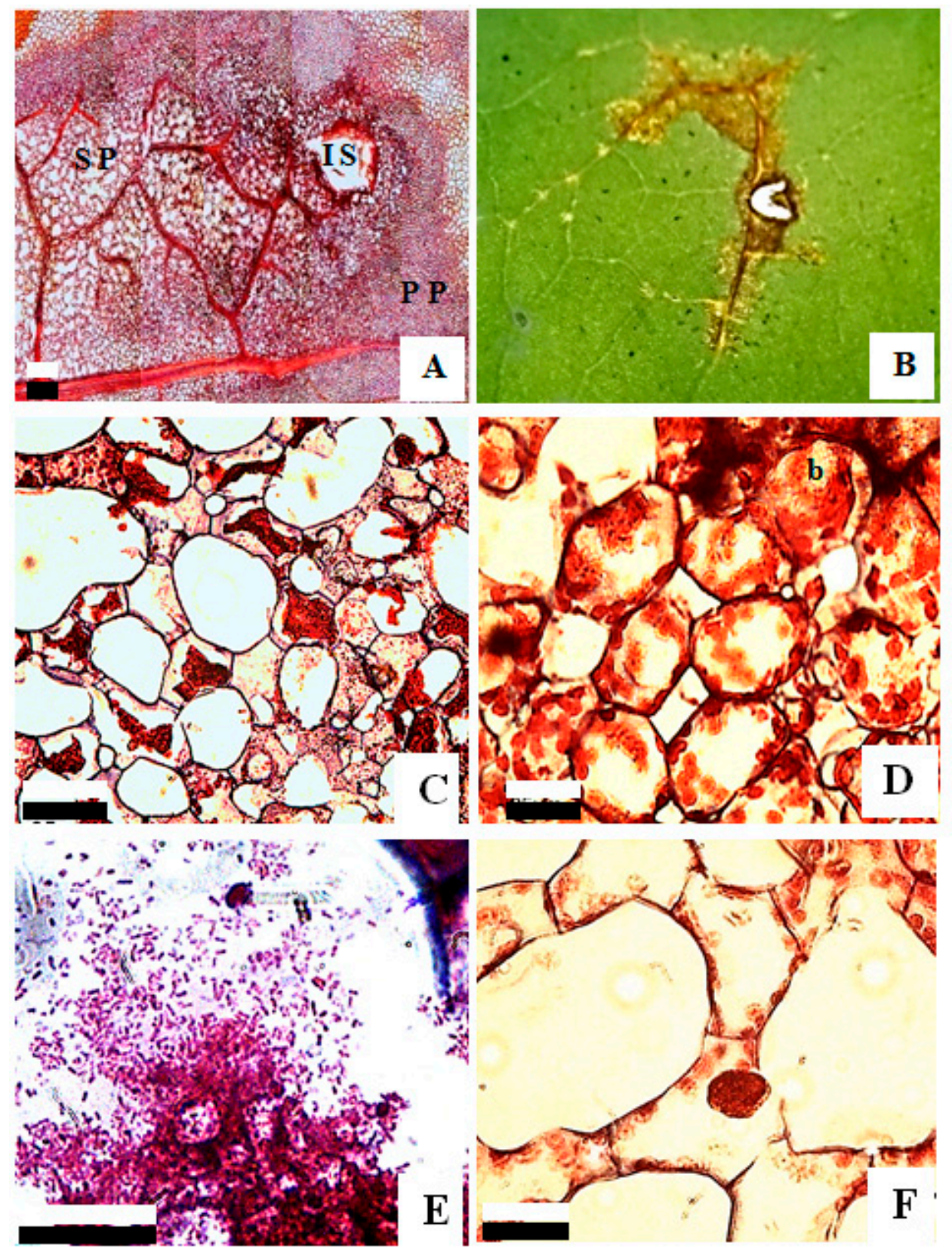

Figure 3. Paradermal section showing mesophyll in the inoculation site at 20 DAI. Disrupted mesophyll cells distant from inoculation site (A); external symptoms with path of the ribs (B); destruction of chloroplasts of spongy parenchyma (C); Transverse section of leaf showing hyperplasia in the spongy parenchyma (D); bacterial mass present in the intercellular space of spongy parenchyma (E); and inclusions (F) present in spongy parenchyma cells. $b=$ bacteria; IS = inoculation site, PP = palisade parenchyma; $\mathrm{SP}=$ spongy parenchyma. $(\mathrm{Bar}=25 \mu \mathrm{m})$.

of the bundle sheath and into the vascular system of the minor vein, moving from there to the midvein and shifting to other more distant regions of the plant, thereby promoting the long-term survival of the pathogen. Our results support this hypothesis by showing that, when inoculated near a vascular bundle, bacteria spread more easily to other internal tissues that were farther from the inoculation site, suggesting the movement of the pathogen through conductor bundles (Figures 2E, $2 \mathrm{~F}, 3 \mathrm{~A}, 3 \mathrm{~B})$. Based on this piece of information, it seems reasonable to assume that in coffee the apex death of seedlings, frequently observed in nurseries and caused by $P$. syringae pv. garcae, could be due to the transport of bacteria through the xylem vessels.

Presence of bacteria in vascular bundles confirms the hypothesis of locomotion and/or transport to regions distant from the colonization site by the pathogen. P. syringae pv. garcae causes the death of leaves and branches by moving more rapidly in the apex direction through the xylem. Additionally, leaves and branches below the colonization site could be infected through the phloem, which can result in the death of diseased plants.

Our results can be helpful in understanding the colonization mode by $P$. syringae pv. garcae in leaf tissue, as well as the bacterium-coffee 
interaction. Furthermore, they are important in assisting coffee breeding programs for resistance to bacterial halo blight.

\section{ACKNOWLEDGMENTS}

This study was supported by CAPES in the form of sponsorship of the first author. The authors thank Dr. Suzete A. Lanza Destéfano, curator of IBSBF Culture Collection, for providing the bacterial strain used in this study, Dr. Julio Rodrigues Neto and Dr. Albertus Bernardus Eskes, for their helpful suggestions.

\section{REFERENCES}

1. Amaral, J.F.; Teixeira, C.G.; Pinheiro, E.D. O bactério causador da mancha aureolada do cafeeiro. Arquivos do Instituto Biológico, São Paulo, v.23, p.151-155, 1965.

2. Arrebola, E; Cazorla, F,M.; Perez-García, A.; Vicente, A. Chemical and metabolic aspects of antimetabolite toxins produced by Pseudomonas syringae pathovars. Toxins, Basel, v.3 p.1089-1110, 2011.

3. Bender, C.L.; Alarcon-Chaidez, F.; Gross, D.C. Pseudomonas syringae phytotoxins: mode of action, regulation, and biosynthesis by peptide and polyketide synthetases. Microbiology and Molecular Biology Reviews, Washington, v.63, n.2 p.266-292, 1999.

4. Chen, Z.J. Morphocultural and pathogenic comparisons between $\mathrm{Col}$ letotrichum kahawae and . gloeosporioides isolated from coffee berries 2002. 163f. Tese (Doutorado em Engenharia Agronômica) - Universidade Técnica de Lisboa, Lisboa, Portugal, 2002.

5. Costa, A.S.; Amaral, J.F.; Viegas, A.P.; Silva, D.M.; Teixeira, C.G.; Pinheiro, E.D. Bacterial halo blight of coffee in Brazil. Phytopathologische Zeitschrift, Berlin, v.28, p.427-444, 1957.

6. Hattingh, M.J.; Roos, I.M.M.; Mansvelt, E.L. Infection and systemic invasion of decidous fruit trees by Pseudomonas syringae in South Africa. Plant Disease, St. Paul, v.73, n.10, p.784-789, 1989.

7. Johansen, D.A. Plant microtechnique. McGraw-Hill, New York. 525p. 1940.

8. Korobko, A.; Wondinagegne, E. Bacterial blight of coffee (Pseudomonas syringae pv. garcae) in Ethiopia. In Rudoldh, K., Burr, T.J., Mansfield, J.W., Stead, D., Vivian, A. Von Kietzele, J. Pseudomonas syringae pathovars and related pathogens. Dordrecht, Springer, 1997, p. 538-541.

9. Misas-Villamil, J.C.; Kolodziejek, I.; Van Der Hoorn, R.A.L. Pseudomonas syringae colonizes distant tissues in Nicotiana benthamiana through xylem vessels. The Plant Journal, Michigan, v.67, p.774-782, 2011.

10. Palmer, D.A.; Bender, C.L. Ultrastructure of tomato leaf tissue treated with the pseudomonad phytotoxin coronatine and comparison with methyl jasmonate. Molecular Plant-Microbe Interactions, St. Paul, v.8, p. 683-692, 1995.

11. Pereira, I.S.; Abreu, M.S.; Alves, E.; Ferreira, J.B. Estudos histopatológicos da interação Colletotrichum gloeosporioides-cafeeiro. Bragantia, Campinas, v.68, n.1, p. 117-123, 2009.

12. Queiroz-Voltan, R.B.; Paradela Filho, O.; Carelli, M.L.C.; Fahl, J.I. Aspectos estruturais de cafeeiro infectado com Xylella fastidiosa. Bragantia, Campinas, v.57, n.1, p.23-33, 1998.

13. Ramos, A.H.; Shavdia, L.D. A dieback of coffee in Kenya. Plant Disease Reporter, St. Paul, v.60, n.10, p.831-835, 1976.

14. Rodrigues, L.M.R.; Comparoni, R.; Almeida, I.M.G.; Patricio, F.R.A.; Beriam, L.O.S.; Guerreiro-Filho, O. Aggressiveness of Pseudomonas syringae pv. garcae strains in Coffea arabica cvs. Mundo Novo and Bourbon Amarelo (PB218). In: 24 $4^{\text {th }}$ International Conference on Coffee Science, 24, San José, Costa Rica, Proceedings. ASIC, 2013, p.1362-1364.

15. Roos, I.M.M.; Hattingh, M.J. Systemic invasion of cherry leaves and petioles by Pseudomonas syringae pv. morsprunorum. Phytopathology, St. Paul, v.77, n.9, p.1246-1252, 1987.

16. Sera, T. Coffee genetic breeding at IAPAR. Crop Breeding and Applied Biotechnology, Viçosa, v.1, p.179-190, 2001.

17. STATSOFT. Statistica: data analysis software system: version 7.0. Tulsa: Statsoft, 2004.

18. Steel, R.G.D.; Torrie, J.H. Principles and procedures of statistics, a biometrical approach. 1980, 2. ed. New York: Mc Graw-Hill, 481p.

19. Voltan, R.B.Q.; Cabral, L.P.; Paradela Filho, O. Avaliação preliminar do efeito do Colletotrichum spp. na estrutura de plantas de cafeeiro. In: Congresso Brasileiro de Pesquisas Cafeeiras 28, 2002, Caxambu. Trabalhos apresentados. Rio de Janeiro: MAPA/Procafé, 2002, p.364-365.

20. Zambolim, L.; Vale, F.X.R.; Zambolim, E.M. Doenças do Cafeeiro. In: Kimati A., Amorim L., Rezende J.A.M., Bergamin FILHO A., Camargo L.E.A. Manual de Fitopatologia. 2005, 4.ed. São Paulo: Agronômica Ceres, p.165-180.

21. Young, J.M.; Dye, D.W.; Bradbury, J.F.; Panagopoulos, C.G.; Robbs, C.F. A proposed nomenclature and classification for plant pathogenic bacteria. New Zealand Journal of Agricultural Research, Wellington, v.21, p.153-177, 1978. 